Covered in: Web of Sciences (WOS); EBSCO; ERIH+; Google Scholar; Index Copernicus; Ideas RePeC; Econpapers; Socionet; CEEOL; Ulrich ProQuest; Cabell, Journalseek; Scipio; Philpapers; SHERPA/RoMEO repositories; KVK; WorldCat; CrossRef; CrossCheck

2020, Volume 12, Issue 1 Sup. 1, pages: 330-346 | https://doi.org/10.18662/rrem/12.1supl/238

\section{Developing the}

Content of Forming

the System of

Intending History

Teachers

Professional

\section{Competence Using Multimedia Technologies}

\section{Andriy HRY'TSENKO ${ }^{1}$}

${ }^{1}$ Candidate of Pedagogical Sciences, Senior Lecturer Oleksandr of Dovzhenko Hlukhiv national pedagogical university / doctoral student of the National Pedagogical Dragomanov University, Hlukhiv, Ukraine, metodistandre@gmail.com
Abstract: In the current research the components of the system of forming the professional competence of intending History teachers using multimedia technologies were investigated and elaborated. The purpose of the research is to present the specified system as an integral, multicomponent education, to determine its content and structure. Research methods include a practical study by the authorof the process of forming components of the proposed system in three stages: diagnostic, content-practical and analytical-summarizing with the use of research methods; analysis of the results of the systematic implementing multimedia tools in the educational process in combination with theoretical analysis of the scientific from different countries of the world. The study concludes that the developed system of forming the professional competence of intending History teachers using multimedia technologies includes five components - motivational-value, informationcognitive, operational-activity, creative-projective and evaluative-reflexive, the effectiveness of which is ensured by the system and procedural integrity due to the interconnectedness and interdependence of these components. Moreover, the effectiveness of functioning this system depends on a number of pedagogical conditions: introducing the author's multimedia educational tools to the educational process; updating traditional and introducing innovative methods of teaching social-humanitarian and methodologicalhistorical disciplines with the use of multimedia educational tools; the combination of reproductive and productive methods; providing intending History teachers with the necessary set of knowledge, skills and abilities to work with multimedia programmes and educational tools; introducing the elements of distance learning to training the intending teachers; using the appropriate material and software providing the educational process, creating the author's multimedia educational tools.

Keywords: professional competence; system; multimedia technologies; teachers; History; competence.

How to cite: Hrytsenko, A. (2020). Developing the Content of Forming the System of Intending History Teachers Professional Competence Using Multimedia Technologies. Revista Romaneasca pentru Educatie Multidimensionala, 12(1Sup1), 330-346. https://doi.org/10.18662/rrem/12.1sup1/238 



\section{Introduction}

The development of modern education is based on a competent approach as one of the strategic directions of development of the educational sphere and the main provision of the modernization of the structure, content and organization of education. In the course of the research we studied the international experience and elaborated the components of the system of forming the professional competence of intending History teachers using multimedia technologies. The development of the system is based on the needs and requirements of the informatization of education with the aim of the didactic, educational-methodical and information-technological support of the educational process.

The article is aimed at presenting the system as a coherent, managed, multicomponent entity reflecting the educational process. Moreover, the system is able to function effectively if its separate components are coordinated.

\section{Literature review}

In the process of analyzing the historical and pedagogical literature we concluded that the problem of forming the professional competence in intending teachers is actively investigated by scientists. In particular, aspects of the development of professional competence and criteria for the diagnosis of its levels of formation were investigated by Boholyubov (2014), Bondar (2008), Epstein \& Hundert (2002), Gluzman et al. (2018), Kunter et al. (2013), Lauermann \& König (2016), Masyukova (2015), Savchenko (2011), Van der Vleuten et al. (2010), Zablots'ka (2009), Zhumabaeva et al. (2016)

The peculiarities of forming subject-historical competences were investigated by Bakhanov \& Myroshnychenko (2018), Maliyenko (2016), Pometun \& Freiman (2004), Vlasov (2010).

Despite this level of the scientific research, the problem of the content of forming the professional competence of intending History teachers with the use of multimedia technologies in modern conditions has not yet been sufficiently investigated in the pedagogical theory and pedagogical practice. At the same time there are a number of contradictions, in particular between the increasing requirements for teaching History to students using multimedia technologies and the lack of the system of scientific and methodological support at each stage of studying; between the psychological ability of students to quickly accumulate knowledge and skills 
to apply everything new and progressive and insufficient motivation and, as a consequence, the experience of teachers, insufficient consideration of the specific use of multimedia in the process of teaching History.

\section{Methodology}

In order to carry out the study of the content criteria for forming the professional competence of intending History teachers using multimedia technologies we used a number of research methods: theoretical analysis of the scientific literature in order to clarify the status of the problem under study; modelling in order to determine the impact of the competence approach on forming the system of use of multimedia technologies in the process of teaching History in the pedagogical higher education institutions.

Besides, the practical study of the process of forming the components of the proposed system, occurred in three stages: diagnostic, content-practical and analytical-summarizing. Moreover, each of them envisaged the use of different, specific research methods: studying the initial level of forming each component of the professional competence of intending History teachers according to certain criteria and indicators in the course of questioning, conducting surveys, testing; introducing multimedia educational tools into the process of the professional development of intending teachers; analysis of the results of the systematic implementation of multimedia tools into the educational process of training intending History teachers with the formation of their professional competence, as well as mastering the participants of the pedagogical experiment of the whole set of modern methods of teaching History with the choice among them the most effective ones in functioning the information and communication pedagogical environment.

According to the views of the researchers S. Hamzin, M. Kenenbaeva, T. Kenzhebayeva, J.Sakenov, A. Tleulesova, Z. Zhumabaeva, and A. Zhumasheva the criteria for of professional competence of students as intending teachers include the following: educational and cognitive (assimilating knowledge, the level of the professional literacy); personal and motivational (a person's qualities and characteristics, tolerance, psychological readiness for the professional duties; ready to be responsible for the results of the professional activities; awareness of methods of teaching and readiness for the professional selfeducation and self-development); empirical (mastering professionallyoriented actions, ability to work efficiently, applying knowledge in nonstandard situations, developing skills of planning, organizing and realizing 
the professional activities, ability to apply modern information aids and information technologies.

\section{Defining the fundamental aspects of the system functioning}

The defined system of forming the professional competence of intending History teachers using multimedia technologies is based on introducing the main scientific approaches (competence, system, personal, activity, energy, axiological, cultural, acmeological) which are methodological grounds and basic factors of using multimedia technology.

The competence approach provides an update on training intending History teachers by shifting the focus from the content to learning outcomes, from knowledge to personality development and achievement of integrative character, correlating it with the value-meaning characteristics of the personality and having a practice-oriented approach. For example, in Slovakia, competencies, especially the key ones, are included into the national educational programme as the fundamental component (Lane \& Bourke, 2017).

The systematic approach provides investigating the professional competence of intending History teachers as a multidimensional concept of interdependent and interrelated elements and allows understanding the natural connections between the structural components of the given educational phenomenon.

The personal approach places the professional competence of intending History teachers first and foremost on their personality.

The activity approach is based on the priority of activity as a decisive factor in the development and professional realization of the intending History teacher, one of the main parameters of the structure of his/her professional competence.

The synergistic approach is the reason to consider the professional competence of intending History teachers in its constant development and self-development in accordance with the universal laws of the evolution of nature, society and human.

The axiological approach allows us to consider understanding the values of history and the social and humanitarian disciplines, with the understanding of the values of their knowledge as an important strategy for the professional development of the History teacher.

The cultural approach provides defining the pedagogical phenomenon of the professional competence of intending teachers of History which consists in the training cultural and moral personality with 
the objective realization of goals, needs, ideals in worldview and outlook on the broad socio-cultural background of the development of information and communication media, in particular, cultural and moral media.

From the point of view of the acmeological approach based on the interdisciplinary science that emerged at the boundary of natural, social and humanities disciplines higher achievements in the holistic professional and personal development of intending teachers of History in the course of forming their professional competence using multimedia technologies take place.

The basic theoretical factor of developing the system of forming the professional competence of intending History teachers with the use of multimedia technologies included the basic principles of the historical education: informatization of the education which creates conditions for the intensification of the educational process based on the use of the latest information and communication technologies; the optimal choice of teaching tools which led to the development of the own educational tools based on multimedia technologies; the visibility that in the conditions of functioning the information-communication pedagogical environment becomes the principle of multimedia appliance; integration of the traditional teaching methods of History and social sciences and humanities with the innovative multimedia technologies which permeates all kinds of the educational pedagogical activity of intending teachers of History; activation of subject-historical activity and development of skills to use the pedagogical influence of the educational subject which is motivation of creative manifestations of intending teachers of History with the use of multimedia technologies.

In addition, the process of forming the professional competence in intending teachers of History is subject to: mastering the theoretical foundations, means and methods of performing professional tasks; ability to analyze, predict the activities and independently choose the means and methods of action in certain specific situations; the ability to selfdevelopment and self-realization in the conditions of mastering the modern scientific achievements and their introducing and the positive attitude to the future professional activity (Hrytsenko, 2019a: 250).

The component composition of the system of forming the professional competence of intending History teachers with the use of multimedia technologies is the interrelation of the motivational-value, information-cognitive, operational-activity, creative-projective, evaluativereflexive components that integrally cover its content. The interconnection of the components ensures the systematic and procedural integrity of 
forming the professional competence of the intending History teachers using multimedia technologies and the quality of each component is determined by the criteria and indicators of the development.

We are convinced that the concept of "criterion" and "indicator" should be considered based on the traditional scientific and pedagogical view of the criterion as a benchmark for determining, evaluating the subject, phenomenon. In the pedagogical theory and practice criteria are usually considered together with the narrower meaning of the term "indicator" - the degree of manifestation, qualitative formation, certainty of the criteria which are expressed by the specific indicators (Kozak, 2013).

Therefore, in accordance with the purpose of our study the criteria of the professional competence of intending History teachers are understood as the set of characteristics peculiar to a particular aspect of the professional training of History teachers and the indicators are quantitative and qualitative characteristics of the formation of these characteristics. In our view, a number of key components are included in the system of the professional competence forming of intending History teachers using multimedia technologies.

\section{Motivational value component of the system}

The motivational and value component of the system of forming the professional competence of intending History teachers using multimedia technologies indicates the intending teachers' desire to master the professional knowledge, skills, personal development with the help of multimedia which will ensure their further successful teaching History and humanities in general secondary education institutions. This component of the system will be effective provided the transition to a qualitatively new level of the professional development which will be ensured by the use of multimedia tools. Teachers' applying multimedia authoring packages constantly increases as a means of assisting mastering subjects in a range of curricula areas. In this case, students develop their own multimedia texts in the form of websites or CD-ROMs, mostly combining the written texts, visual images, elementary animation, audio and video materials (SeftonGreen, Buckingham,1996).

Intending teachers of History should develop the positive motivation for the profession by means of the intensification of educational and cognitive activity, a steady interest in mastering historical knowledge, the application of skills in practice as well as the desire to have a positive result of their pedagogical skills due to the diversity of systematic learning and 
form complexity in their self-assessment of the professional activity (Hrytsenko, 2019b: 62). For this purpose, forming their professional competence should be their personal product, which demonstrates a comprehensive readiness for the professional activity, the development of knowledge, skills and psycho-pedagogical and professional-historical direction, the possession of modern information and communication, in particular, multimedia technology and the need for the constant development of their personal and professional qualities.

To develop the motivational and value component of the system of forming the professional competence of intending History teachers using multimedia technologies we developed our own conceptual model based on the philosophical and psychological-pedagogical interpretation of the concept of "motivation" (from Latin motivatio), which is considered as a system of internal factors which orient and direct the behavior of a person towards the goal, as an internal motivation to action which determines the subjective-personal interest of the individual in its accomplishment (Ilyichev, 1983). From the point of view of psychology motivation is made up by the motives that cause the activity of an organism and determine its orientation. Based on the theoretical definitions of motivation we attempted to form the desire for the future professional development of the History teachers, oriented to the modern requirements of the information society, forcing them to acquire the professional knowledge and skills by means of multimedia.

To ensure the sustainable motivation for the use of multimedia technologies in the professional development of intending History teachers, students were acquainted with the existing multimedia products in History and social sciences (electronic textbooks, manuals, electronic historical atlases, informational and electronic publications, electronic media, online resources), children's game historical educational editions, test programmes to control the historical knowledge and skills using multimedia tools etc.

The motivational and value component in the developed system is represented by such a criterion as the degree of focus on the use of multimedia in the professional training. Its indicators are as follows:

- formation of the need to use multimedia educational tools;

- clarity of the need to use multimedia educational tools in the professional education.

Thus, the motivational-value component implies the development of intending History teachers' interest in modern information and communication educational technologies, forming the stable need for 
applying computer, in particular multimedia technologies, in the future professional activity.

\section{Information-cognitive component of the system}

The informative-cognitive component of the system of forming the professional competence of intending History teachers using multimedia technologies provides assimilation of psychological-pedagogical, professional historical-theoretical and methodological knowledge using multimedia textbooks, manuals, other multimedia educational media technologies that ensure the successful use of multimedia.

Developing this concept we are convinced that, first of all, it is necessary to use multimedia tools, first and foremost, in the professional disciplines of historical and theoretical content, namely in courses of historical-methodical and social-humanitarian disciplines. These professionally oriented subjects usually require the involvement of a large number of different information sources: textbooks, manuals, articles, primary sources, monograph studies on relevant problems, and separate articles. These training materials are currently added to Internet resources. After all, due to the possibilities of multimedia technologies everything is combined in one textbook (educational-methodical complex, electronic educational resource etc.), which creates conditions for organizing more effective students independent work, development of creative projects etc. Professional historical and methodological disciplines are mainly focused on the traditional teaching methods and involve the use of multimedia in a much smaller (rather limited) amount.

Lachs (2000) describes intending teachers in the process of learning history. Such projects generally involve the most challenging aspects of the work which is mainly interactive: the students have to do hard intellectual work on how different users might interpret and apply their products, and the way they will navigate around.

Therefore, in order to provide the modern level of teaching the historical-methodological and social-humanitarian disciplines in the professional training of intending teachers of History, soundness and strength of the theoretical and didactic knowledge, we developed and put into practice multimedia textbooks and electronic manuals.

The next component of the information-cognitive component of this system is the multimedia knowledge set necessary for successful use of the existing multimedia educational tools and creating the own ones. Formaing this component during the pedagogical experiment occurred in 
the process of mastering the special course "Multimedia technologies in historical education": review of hardware and software of multimedia in History, acquisition of the theoretical and methodological knowledge on the use of multimedia in the subject area, tools suitable for use in general education institutions, major Windows 2017 software packages (PowerPoint, MovieMaker, MicrosoftPaint), graphic editors to provide multimedia support for History lessons and social sciences and the like.

The informative-cognitive component allows to measure, by a certain criterion, the degree of formation of the professional-historical thesaurus, historical, theoretical and didactic knowledge related to the use of multimedia technologies in the process of learning History, as well as the knowledge of available educational and developmental means of historyhumanities disciplines indicators of this criterion are:

- volume of knowledge in the professionally oriented courses in historical-methodical and social-humanitarian disciplines;

- awareness of multimedia tools in History and social sciences subjects.

\section{The operational and activity component of the system}

The operational and activity component of the system of forming the professional competence of intending teachers of History using multimedia technologies indicates forming intending History teachers' practical skills of using multimedia tools in their own professional development and the further pedagogical and methodological activity in the secondary education.

This component provides the practical dimension to the success and effective professional work of intending History teachers, provided that they have mastered the skills and competences developed with the help of multimedia in the process of learning professionally oriented disciplines:

- mapmaking skills - using electronic atlases where one can zoom in, make extra map layers, create hyperlinks.

- historical and analytical skills in using multimedia as teaching aids;

- computer creativity skills related to developing one's own electronic, including multimedia products (presentations, visualizations, slideshows, etc.).

- video skills while using computer technology to view, edit, and create relevant videos about historical events and figures in multimedia textbooks and in the Internet. 
Besides, the operational-activity component of the system provides intending history teachers with the ability to use multimedia teaching aids at History lessons and extracurricular educational activities. Among them there are the following:

- skills and creative skills in the use of multimedia tools: developing the own educational electronic resources;

- developing History lessons and social and humanitarian disciplines with multimedia support;

- ability to organize and carry out control of historical knowledge, skills of students with the use of multimedia; this includes working out basic test programs (MyTestX, HotPotatos, etc.), conducting computer testing using various types of multimedia content test tasks, developing historical quizzes, puzzles, crossword puzzles, involving test tasks from the existing training and test tasks to test knowledge of historical events, facts and phenomena; tests to consolidate and intermediate control of knowledge about the life and work of historical figures etc.);

- development of the procedural and technological skills: development of basic programmes for editing audio, video, images, photos etc.

Operational and activity component reflects the degree of formation of skills of historical and pedagogical work in multimedia educational environment which provides mastering professionally oriented History and social and humanitarian disciplines in terms of the information and communication pedagogical competence of intending History teachers with the use of multimedia technologies.

\section{Creative and projective component of the system}

The creative and projective component of the system of forming the professional competence of intending History teachers using multimedia technologies implies the ability of intending History teachers to organizational and creative searches in the field of multimedia in the further professional activity, demonstrates the ability to create their own multimedia tools. Creative nature of pedagogical activity is its most important objective characteristic. According to Gutierrez (2003) media literacy is of great importance for people's utilizing the appropriate procedures while critically viewing different types of media (different in functions or systems of symbolic representation) so that it will be possible to assess the events in the world and improving it to the maximum possible extent. 
The key to effective forming the professional competence of intending History teachers is the ability to stimulate their creative activity, creativity, as well as to encourage the subject-historical activity and the development of skills to use the educational influence of the subject by means of multimedia technologies. It is caused by the variety of the pedagogical situations and their ambiguity requires differentiated approaches to analysing and solving the occurring problems (Mirza, 2013). Intensive creative activity implies the availability and actualization of the historical and theoretical knowledge, which becomes the basis for the creation of new historical or pedagogical projects, in our study - own multimedia accompaniment to History lessons in the institutions of general secondary education, electronic manuals on specific problems (according to the curriculum) separate articles for multimedia backgrounds, test programmes for the control of historical knowledge and skills using multimedia tools, etc.

While developing this component of the system of the professional competence of intending History teachers using multimedia technologies we came to understanding the concepts of "creativity", "historical subject matter", "patriotic education" existing in the national philosophy, psychology and social studies. The results of creative activity are distinguished by originality, uniqueness, even when it comes to subjective novelty of creative manifestations of personality.

The ability for creativity and subject-historical activity is an important quality of the professional competence of intending History teachers, however, in our study, we place the emphasis on the historicalresearch activities by means of the involvement of multimedia technologies. That is why the creative and projective component of the system of forming the professional competence of intending History teachers is guided by such a criterion as a measure of the ability to creatively and objectively use the existing multimedia educational tools in the professional activity (conducting History lessons) and to create their own electronic educational resources.

\section{Evaluation and reflexive component of the system}

Evaluation and reflexive component of the system of formingthe professional competence of intending History teachers using multimedia technologies determines the formation of the ability to critically evaluate multimedia initial means inHistory, to make the selection of the electronic educational resources and the ability to reflexively evaluate and analyse the power and meaningful activity technologies. 
This component provides for the formation of the value orientations in the field of modern educational tools created on the basis of multimedia technologies; developing a critical perspective on the content and multimedia content of e-learning resources, the ability to analyse multimedia teaching aids regarding the perspective of their use in the activities of History teachers, and the like. The evaluative-reflexive component of the system is also aimed at professional self-improvement of the personality of the intending History teachers, i.e. purposeful, systematic and creative independent activity and expansion of the professional knowledge, development of skills, abilities, personal growth, which will be carried out with the involvement of multimedia tools.

The evaluation-reflexive component, through the criterion of the measure of the formation of personal value landmarks in the field of multimedia in History, as well as the ability to self-analysis and selfdevelopment and the professional activity with the involvement of the multimedia technologies is realized in the following indicators:

- the ability to adequately evaluate multimedia educational tools in History and e-learning resources;

- the ability to professionally improve in the activities of History teachers using multimedia educational tools.

According to the results of the study of the professional competence of intending History teachers in the logic of forming the components of the suggested system, there were three stages: diagnostic (studying the initial level of formation of each component of the professional competence of intending History teachers according to certain criteria and indicators in the course of questioning, conducting surveys, testing); substantive-practical (introducing into the process of professional development of intending teachers of History multimedia educational tools and organization of independent historical-research and subject-pedagogical activities of students using multimedia educational tools), analytical and summarizing (analysis of the results of the systematic means of education stories with the formation of their professional competence).

Developing the system of the professional competence of intending History teachers by means of multimedia technologies required mastering the whole complex of modern methods of teaching History, choosing among them the most effective ones in the conditions of functioning the information and communication pedagogical environment. In the course of the implementation of the experimental system we identified and tested the following methods, which can be grouped into three types (passive, active and interactive): 
Passive (conditionally passive) methods, when the teacher through lectures-monologues, reading (methods of teaching), demonstrations (methods of visualization/demonstration), surveys (online control of knowledge and skills) becomes the source of the historical information, while students are the 'object' of teaching.

Active methods related to fulfilling creative tasks (often at home), dialogue and communication during the conversation with the development of creative thinking, when students become "subjects" of learning, perform creative tasks.

Interactive methods involve continuous interaction, coworking, communication, collaboration of teachers and learners with the emphasis on coordination of the teacher of interactive interaction of students with the effective communication. This type can also be attributed to the problem search method (formulating problem questions, formulating problematic search tasks).

\section{Results}

Thus, as a result of the theoretical research and organization of the pedagogical experiment, the content and structure of our system of forming the professional competence of intending teachers of History using multimedia technologies, which includes five components - motivationalevaluative, information-cognitive, operational-activity, creatively projective and evaluative-reflective were defined. Its efficiency is ensured by the systematic and procedural integrity due to the interconnectedness and interdependence of these components.

It was also defined that the effective functioning the system of forming the professional competence of intending History teachers using multimedia technologies can be ensured by creating and adhering to the following pedagogical conditions: introducing the author's multimedia educational tools into the educational process; updating the traditional and introducing innovative methods of teaching social-humanitarian and methodological-historical disciplines with the use of multimedia educational tools; combination of reproductive and productive methods of teaching History with the involvement of the multimedia means, provided priority of the practical activities with the use of multimedia; providing intending teachers of History with the necessary set of knowledge and skills to work with multimedia programmes and teaching aids, providing pedagogical management of this process; introducing the elements of distance learning to the professional training of the intending History teachers; use of 
appropriate material and software providing of the educational process, creating the own multimedia educational tools.

\section{References}

Bakhanov, K. O., \& Myroshnychenko, V. O. (2018). Formuvannya predmetnykh kompetentnostey zasobamy proektnoho navchannya [Forming subject competences by means of project training]. Ukraine, Kharkiv: Osnova Publishing Group [in Ukrainian].

Bondar, B. (2008). Konkurentozdatnist' pedahoha yak skladova yoho profesiynoyi kompetentnosti [The teacher's competitiveness as a component of the professional competence]. Ukraine, Kyiv: Publishers of Genesis. Pochatkova shkola, 7, 22-23

Boholyubov, V. M. (2014). Teoretychni i metodychni zasady formuvannya profesiynoyi kompetentnosti maybutnikh ekolohiv v umovakh perekhodu do staloho rozvytku Theoretical and methodological bases of forming professional competence of future ecologists in the conditions of transition to sustainable development]. (Doctoral dissertation). Ukraine, Kyiv: National University of Life and Environmental Sciences of Ukraine [in Ukrainian].

Epstein, R. M., \& Hundert, E. M. (2002). Defining and Assessing Professional Competence, Journal of American Medical Association. 287(2), 226-235). Retrieved from: https://jamanetwork.com/journals/jama/articleabstract/194554

Gluzman, N.A., Sibgatullina, T.V., Galushkin, A.A., \& Sharonov, I.A. (2018). Forming the basics of future mathematics teachers' professionalism by means of multimedia technologies. Eurasia Journal of Mathematics, Science and Technology Education. 14(5), 1621-1633. https://doi.org/10.29333/ejmste/85034

Gutierrez, M. A. (2003). Multimedia authoring as a fundamental principle of literacy and teacher training in the information age. In B. Duncan, \& K. Tyner, (Eds.), Visions/ revisions. Moving forward with media education. (pp. 12-22). USA, Madison, WI: National Telemedia Council. Retrieved from: https://www.academia.edu/27023698/MULTIMEDIA AUTHORING AS A FUNDAMENTAL PRINCIPLE_OF_LITERACY AND TEAC HER TRAINING_IN THE_INFORMATION_AGE

Hrytsenko, A. (2019a). Osoblyvosti struktury profesiynoyi kompetentnosti maybutnikh uchyteliv istoriyi $\mathrm{v}$ informatsiynomu suspil'stvi [Features of the structure of professional competence of intending History teachers in the information society]. In L. L. Makarenko (Ed.), Naukowyi chasopys. National Pedagogical Dragomanov University. Series 5 Pedagogical sciences: reality and perspectives. Issue 68 (pp. 61-64). Ukraine, Kyiv: Publishers of 
Developing the Content of Forming the System of Intending History Teachers ... Andriy HRYTSENKO

National Pedagogical Dragomanov University. Retrieved from: http://chasopys.ps.npu.kiev.ua/archive/68-2019/16.pdf

Hrytsenko, A. (2019b). Umovy formuvannya profesiynoyi kompetentnosti v pedahohichniy praktytsi pidhotovky maybutnikh uchyteliv istoriyi [Conditions of forming the professional competence in pedagogical practice of training History teachers]. In I. Bohdanov (Ed.), Scientific Papers of Berdiansk State Pedagogical University. Series: Pedagogicalscientces. Issue 1. BJP Science Notes. Series: Pedagogical Sciences. Issue 1. (pp. 245-254). Ukraine, Berdiansk: BSPU. https://doi.org/10.31494/2412-9208-2019-11-245-254 [in Ukrainian].

lyichev, L. F. (Ed). (1983). Filosofskiy entsiklopedicheskiy slovar' [Philosophical Encyclopedic Dictionary]. Russia, Moscow: Soviet Encyclopedia [in Russian].

Kozak, L. V. (2013). Kryteriyi hotovnosti maybutnikh vykladachiv doshkil'noyi pedahohiky i psykholohiyi do innovatsiynoyi profesiynoyi diyal'nosti [Criteria of intending pre-school pedagogy and psychology teachers' readiness for innovative professional activity]. S. Sysoyeva (Ed.), The pedagogical process: theory and practice. No. 3. (pp. 76-88). Ukraine, Kyiv: Edelweiss. Retrieved from: http://irbis-nbuv.gov.ua/cgibin/opac/search.exe?I21DBN=LINK\&P21DBN=UJRN\&Z21ID $=\& S 21$ $\underline{\mathrm{REF}}=10 \& \mathrm{~S} 21 \mathrm{CNR}=20 \& \mathrm{~S} 21 \mathrm{STN}=1 \& \mathrm{~S} 21 \mathrm{FMT}=\mathrm{ASP}$ meta\&C21COM=S \&2 S21P03=FILA=\&2 S21STR=pptp $2013 \quad 3 \quad 10$ [in Ukrainian].

Kunter, M., Klusmann, U., Baumert, J., Richter, D., Voss, T., \& Hachfeld, A. (2013). Professional competence of teachers: Effects on instructional quality and student development. Journal of Educational Psychology, 105(3), 805-820. Retrieved from: https://doi.org/10.1037/a0032583

Lachs, V. (2000) Making Multimedia in the Classroom: a practical guide. UK, London: Routledge. https://doi.org/10.4324/9780203714676

Lane R., \& Bourke, T. (2017). Assessment in geography education: a systematic review. International Research in Geographical and Environmental Education, 1-15. https://doi.org/10.1080/10382046.2017.1385348

Lauermann, F., \& König, J. (2016). Teachers' professional competence and wellbeing: Understanding the links between general pedagogical knowledge, self-efficacy and burnout. Learning and Instruction, 45, 9-19. https://doi.org/10.1016/j.learninstruc.2016.06.006

Maliyenko, Y. B. (2016). Formuvannya istorychnoyi kompetentnosti zasobamy pidruchnyka $\mathrm{z}$ istoriyi serednikh vikiv [Forming historical competence by means of a textbook on the history of the Middle Ages]. In O. M. Topuzov (Ed.), Problems of the modern textbook. No. 16. (pp. 203-212). Ukraine, Kyiv: Pedagogical Thought. Retrieved from: http://www.irbis-nbuv.gov.ua/cgibin/irbis nbuv/cgiirbis 64.exe?I21DBN=LINK\&P21DBN=UJRN\&Z21I $\underline{\mathrm{D}=\& S 21 \mathrm{REF}=10 \& S 21 \mathrm{CNR}=20 \& \mathrm{~S} 21 \mathrm{STN}=1 \& S 21 \mathrm{FMT}=\mathrm{ASP} \text { meta } \& C 21}$ 


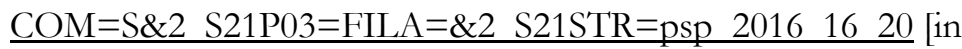
Ukrainian].

Masyukova, N. G. (2015). Metodicheskaya kompetentnost v structure professionalnoj kompetentnosti uchitelya [Methodological competence in the structure of professional competence of teachers]. Mir nauki, kultury, obrazovaniya [World of science, culture, education], 3(52), 67-68. Retrieved from: https://cyberleninka.ru/article/n/metodicheskaya-kompetentnost-vstrukture-professionalnoy-kompetentnosti-uchitelya

Mirza, N. V. (2013). Creative component of professional competence of a teacher. International Journal of Applied And Fundamental Research, 2. Retrieved from: www.science-sd.com/455-24286

Pometun, O. I., \& Freiman, N. O. (2004). Praktyka realizatsiyi kompetentnisnoho pidkhodu v suspil'stvoznavchykh dystsyplinakh [The practice of implementing the competence approach in the social sciences]. In O. V. Ovcharuk (Ed.), Competence Approach in Contemporary Education: World Experience and Ukrainian Perspectives: A Library for Educational Policy. (pp. 105107). Ukraine, Kyiv: "K.I.S" [in Ukrainian].

Savchenko, O. Y. (2011). Kompetentnisnyj pidxid yak chynnyk yakosti profesijnoyi pidgotovkymajbutnogo vchytelya [Competency approach as a factor in the quality of the future teacher's professional training], (pp. 15-22). Formuvannya klyuchovyxi predmetnyx kompetentnostej molodshyx shkolyariv u navchalnomu procesi: teoret. aspekty: dajdzhest 1. Ukl. OV Onopriyenko. Doneczk: Kashtan [in Ukrainian].

Sefton-Green, J. \& Buckingham, D. (1996). Digital visions: Children's creative uses of multimedia technologies. Convergence: The International Journal of Research Into New Media Technologies, 2(2), 47-79.

Vlasov, V. (2010). Yak pereviryty ta otsinyty istorychnu kompetentnist' uchniv: do kontseptsiyi kontrol'nykh robit Derzhavnoyi pidsumkovoyi atestatsiyi z istoriyi Ukrayiny [How to test and evaluate students' historical competence: Towards a concept of control work of the State Final Attestation on the History of Ukraine]. History in Schools of Ukraine, 4, 3-22 [in Ukrainian].

Vleuten, C.P.M. van der, Schuwirth, L.W.T., \& Scheele, F. (2010). The assessment of professional competence: building blocks for theory development. Best Practice \& Research Clinical Obstetrics\& Gynaecology. 24 (6), 703-719. https://doi.org/10.1016/j.bpobgyn.2010.04.001

Zablots'ka, O. (2009). Kontseptual'na model' formuvannya predmetnykh kompetentsiy u studentiv [Conceptual model of forming subject competences of students]. Ukraine, Kyiv: Publishers of Pedagogical press. Shlyakh osvity, 4, 23-28.

Zhumabaeva, Z., Zhumasheva, A., Kenzhebayeva, T., Sakenov, J., Tleulesova, A., Kenenbaeva, M., \& Hamzin, S. (2016). On the Role of Elective Disciplines 
Developing the Content of Forming the System of Intending History Teachers ... Andriy HRYTSENKO

in the Formation of Professional Competence of Students as Future Teachers. International journal of environmental \& science education. 11(15), 66716686. Retrieved from https://files.eric.ed.gov/fulltext/EJ1117763.pdf 